Re-thinking Latin America: Challenges and Possibilities

\title{
Introducción \& Apéndice: América latina ante el espejo (se encuentra con el azogue)
}

\section{Francisco Carballo}

\section{(2) OpenEdition \\ Journals}

Electronic version

URL: http://journals.openedition.org/transtexts/1353

DOI: $10.4000 /$ transtexts.1353

ISSN: 2105-2549

\section{Publisher}

Gregory B. Lee

\section{Electronic reference}

Francisco Carballo, «Introducción \& Apéndice: América latina ante el espejo (se encuentra con el azogue) », Transtext(e)s Transcultures 跨文本跨文化 [Online], 14 | 2019, Online since 31 December 2019, connection on 28 July 2020. URL : http://journals.openedition.org/transtexts/1353 ; DOI : https://doi.org/10.4000/transtexts. 1353

This text was automatically generated on 28 July 2020 .

(c) Tous droits réservés 


\title{
Introducción \& Apéndice: América latina ante el espejo (se encuentra con el azogue)
}

\author{
Francisco Carballo
}

Mi otra pesadilla es la del espejo. Bastan dos espejos opuestos para construir un laberinto.

Jorge Luis Borges, "Siete Noches" En el aire siempre ese olorcito a mierda. Tal vez algunas veces mezclado con sándalo. Ernesto Cardenal, "Cántico Cósmico, Cantiga 33.

Las Tinieblas Exteriores"

Aprendimos que no se escribe en el vacío.

Somos el instrumento y la consecuencia de lo que está pasando tras la ventana en la calle. José Emilio Pacheco, "Imitación de Tu Fu para

Sergio Pitol"

\section{I}

1 Este número especial de Transtext(e)s Transcultures 跨文本跨文化 es la culminación de varios meses de arduo trabajo editorial. Nos interesa trazar un panorama amplio aunque no definitivo de los temas que interesan a los académicos que emplean América latina como su archivo de investigación. La región se ha transformado en los últimos años. El entorno político y económico en 2020 es menos esperanzador de lo que se advertía a principios de siglo, cuando la marea rosada se consolidaba en el continente y las materias primas eran bien pagadas en el mercado internacional.

2 El giro hacia de izquierda, ese que capturó la imaginación del mundo hace dos décadas, está en retirada. En algunos lugares se antoja en bancarrota, en otros sitios apenas 
resiste los embates de sus adversarios y cuando se recupera lo hace con menos fuerza y bastante más resistencias que en sus primeras incursiones electorales. Bolivia, Brasil, Chile, Ecuador, El Salvador, Honduras, Paraguay y Uruguay se han corrido hacia la derecha a la hora de elegir a sus gobernantes. El justicialismo volvió al poder en la Argentina después de un breve paréntesis neoliberal. Alberto Fernández se mueve, sin embargo, con una cautela que no le era propia ni a Néstor ni a Cristina Kirchner. Venezuela paga caro los errores de sus líderes tras veintiún años en el poder. Nicaragua ocupa, en el listado de Transparencia Internacional, el puesto 161 en un escalafón que agrupa a 180 naciones y mide la percepción social de la corrupción. ${ }^{1}$ Cuba quedó suspendida en el tiempo. Es un testimonio de las promesas y los desengaños del siglo XX. La izquierda latinoamericana, en sus variopintas manifestaciones, se encuentra en un período de franco retroceso. Su reinvención resulta un imperativo impostergable.

El colapso económico mundial de 2008 comenzó en las metrópolis occidentales y con inusual lentitud se fue abriendo paso en América latina. ${ }^{2}$ La economía neoliberal, neoclásica la llaman los técnicos, ha regresado a la palestra como consecuencia de la debilidad hacendaria de la mayoría de los gobiernos regionales. Se presenta, igual que en los años ochenta de la centuria pasada, como la amarga medicina para enderezar el rumbo económico. Su programa se condensa a tres palabras fetiche: austeridad, privatizaciones y desregulación. Pasa que las políticas neoclásicas han perdido la legitimidad científica de los que alguna vez gozaron. ${ }^{3}$ En su nueva encarnación, los adalides del neoliberalismo son trolls provenientes de las redes sociales y no tecnócratas con distinguidas credenciales académicas. Atrás quedaron los días de los Chicago Boys, esa generación de expertos que floreció hace ya más de tres décadas y alteró irremediablemente el rumbo de la región. ${ }^{4}$ El neoliberalismo en la segunda década del siglo XXI se ha desprendido su fe en la democracia representativa y esta dispuesto a pactar su permanencia en el poder con políticos de cariz autoritario.

4 La violencia criminal es una amenaza que se extiende desde la frontera mexicana con Estados Unidos hasta las megalópolis del Cono Sur. En ciertos lugares, la mafia presenta un considerable desafío al monopolio del Estado sobre la violencia legitima. En ocasiones, el crimen y el poder político se confunden. ${ }^{5}$ La violación sistemática de los derechos humanos sigue siendo un problema endémico. No obstante, sus formas se han ido transformando en lo que va del presente siglo. A menudo, la tortura, la desaparición y el asesinato son subcontratados por las autoridades a la delincuencia organizada. Con frecuencia, son los criminales quienes usan a las fuerzas de seguridad del Estado para eliminar a sus objetivos, como demuestra el caso de los estudiantes normalistas desparecidos en Iguala, México. ${ }^{6}$ Si durante el siglo XX las crisis latinoamericanas eran políticas y económicas, las crisis que distinguen al siglo XXI son las de seguridad. Baste recordar la tasa de asesinatos por cada 100,000 habitantes. Las cifras resultan aleccionadoras. El Salvador exhibe un promedio de 61,8 homicidios; Venezuela 56,3; Honduras 41,7; Brasil 30,50; Guatemala 26,10; Colombia 24,90; México 24,80. ${ }^{7}$ En países con un índice de criminalidad todavía bajo como Argentina, Bolivia, Chile, Paraguay y Uruguay, el miedo a la criminalidad se avizora como un problema en ascenso y está dominando la agenda política.

5 Cada dos horas una mujer es ultimada en América latina. En 2019, tres mil ochocientas mujeres fueron víctimas de feminicidio, es decir, muertas por el hecho mismo de su sexo. ${ }^{8}$ Tal y como sostiene Rita Segato: "El ataque sexual y la explotación sexual de las mujeres son hoy actos de rapiña y consumación del cuerpo que constituyen el lenguaje 
más preciso con que la cosificación de la vida se expresa. Sus deyectos no van a cementerios, van a basurales". 9

6 La corrupción es la principal causa de insatisfacción ciudadana con la democracia como sistema político. ${ }^{10}$ Un nombre captura un fenómeno tan viejo en la zona como la corrupción y que, sin embargo, ha evolucionado considerablemente en sus formas y en sus alcances: Odebrecht. ${ }^{11}$ No es casualidad que el clamor por soluciones a un problema de larga data está llegando a niveles de exasperación. En el Perú, cuatro de los últimos expresidentes (Fujimori, Toledo, Humala y Kucynski) están condenados, indiciados o son prófugos de la justicia. El quinto expresidente de la era reciente, Alan García, se suicidó ante el temor de enfrentar cargos por corrupción. Dos gobiernos de signo ideológico opuesto, el de Otto Pérez Molina en Guatemala y el del Partido de los Trabajadores en Brasil, cayeron, en gran medida, por el hartazgo social ante una clase política que ha hecho del peculado un modus vivendi. López Obrador en México y Nayib Bukele en El Salvador ganaron sus respectivas elecciones enarbolando la lucha frontal contra la corrupción. Sus triunfos resultaron abrumadores.

7 El atractivo de las respuestas simples a problemas complejos es cada vez más difícil de resistir. El populismo, un fenómeno bien conocido en América latina, está cambiando de piel ideológica. Se ha convertido en el patrimonio de la extrema derecha. El autoritarismo se agazapa en el horizonte; esta vez sin tapujos, sin parapetarse en las sombras. Se trata de un autoritarismo que reivindica con orgullo el legado criminal de las dictaduras latinoamericanas del siglo XX. Es tan militante como los más radicales entre sus enemigos y al contrario de la izquierda continental es decididamente antidemocrático. ${ }^{12}$ Como buen populismo desconfía de los pesos y contrapesos que distinguen a las institucionales representativas.

8 A Jair Bolsonaro poco le interesan las meticulosas rutinas que conlleva la administración pública. Dedica su tiempo, en cambio, a hacer proselitismo a favor de una delirante visión del mundo. Tanto la práctica política como el incendiario discurso del presidente Brasileño invitan comparaciones con el fascismo clásico. En El Salvador, Nayib Bukele, está demostrando ser un fiel seguidor de Carl Schmitt. Cree, por ejemplo, en la célebre máxima del jurista alemán: "Soberano es aquel que decide sobre la excepción". Bukele y algunos de sus pares regionales se consolidan en la creación y el manejo de las crisis. En el estado de excepción prescinden, por ejemplo, de la más obvia de las demandas de la sociedad civil latinoamericana, la que exige de sus gobernantes la rendición de cuentas.

En Bolivia, la oposición que expulsó a Evo Morales del poder se ha aglutinado en torno a un vociferante fundamentalismo cristiano. El pastor coreano Chi Hyun Chung y el hijo de una exitosa familia de negociantes, Luis Fernando Camacho, hicieron de la Biblia la antítesis de la Constitución aprobada en 2009. La Ley que declaraba a Bolivia como un Estado laico y plurinacional. La presidenta que se encumbró para sustituir al depuesto Morales, Jeanine Añez, recordó, mientras agitaba una Biblia con tapas de color rosa chillante, de donde le venía la legitimidad: "Gracias a Dios que ha permitido que la Biblia vuelva a entrar a Palacio [Quemado]. Que él nos bendiga y nos ilumine". ${ }^{13}$ Con toda intención simbólica, el crucifijo se ha utilizado para reconquistar el poder y dar por concluida, lo que las élites tradicionales bolivianas, consideran como una revuelta indígena que duró diecinueve largos años. Una insurrección que tuvo su origen en la Guerra del Agua que se libró en Cochabamba durante el año 2000 y se dio por concluida cuando despegó el avión que conducía a Evo Morales hacia el exilio. 

memorables suceden en Facebook son algunos de los rasgos definitorios del panorama contemporáneo. El ministro de educación brasileño, Abraham Weintraub, advirtió a sus malquerientes los peligros que les depara el destino. Lo hizo publicando en Twitter salmo bíblico (94:23): "El Señor hará recaer sobre ellos su propia iniquidad, y los destruirá en su propia malicia; el Señor nuestro Dios os destruirá" ${ }^{15}$ América latina vive en un clima de polarización constante. Se trata de un conflicto que se desenvuelve en términos ideológicos: izquierda contra derecha. Una mirada atenta revela a esas categorías como un tanto huecas. ¿Cuáles son las diferencias de fondo entre un lado y el otro de la grieta ideológica?

Es la mutua antipatía la que da consistencia a los bandos en disputa. "Izquierda" y "derecha" son más conscientes de los defectos que distinguen a sus rivales que de sus propias convicciones. Para concitar el odio es menester personalizar al enemigo. Me refiero a fenómeno indicativo del narcisismo contemporáneo, ese que se reproduce en la redes sociales. La exaltación de los propios méritos descansa en la defenestración del otro. Me refiero a la necesidad de reconocerse a sí mismo al través de la destrucción moral del contrario, entendido como el arquetipo de todo lo que uno aborrece. El debate público se ha convertido en la agregación de un sinnúmero de emociones personales y la política en la administración de las pasiones colectivas. El líder de éxito es aquel que sabe despertar sentimientos sectarios y, para usar una palabra al gusto de Juan Domingo Perón, conducir esas emociones hacia los fines que se ha trazado.

12

Desde el punto de vista programático, unos y otros, izquierda y derecha, suscriben los mismos lugares comunes. Prometen terminar con el lastre de pobreza. Buscan asegurar el crecimiento económico, y de ser posible alcanzar el número mágico: la expansión del producto interno bruto en dos dígitos. Es decir, las cifras que tanto se envidian a las economías asiáticas. Construir proyectos de infraestructura -autopistas, puentes, túneles, aeropuertos, hidroeléctricas, ferrocarriles, refinerías- es todavía la marca inconfundible del éxito en la gestión gubernativa. La aspiración de la justicia social se ha relegado a un asunto puramente educativo. La llaman "igualdad de oportunidades". Tirios y troyanos prometen materializar las hasta ahora escurridizas promesas de desarrollo. La ruta preferida para el progreso económico y social varía según las convicciones filosóficas y, sin embargo, hay similitudes extraordinarias en las recetas al uso. Ambos lados de la zanja se aferran, por ejemplo, al consenso en que descansan las naciones latinoamericanas: la modernización a ultranza.

13 En los próximos años, una buena parte de los países latinoamericanos conmemorarán doscientos años de vida independiente. El mito fundacional de éstas republicas yace en los rancios valores positivistas del siglo XIX: orden y progreso. Hay un tercer pilar de estas sociedades que no suele mencionarse y sin embargo nadie desconoce: el racismo. ${ }^{16}$ La discriminación es la última gran barrera que impide una democratización profunda y necesaria.

14 El extractivismo reina en todo el continente como la manera más rápida para producir ingresos en moneda extranjera. Sus efectos secundarios están causando una devastación social y ecológica a gran escala. ${ }^{17}$ Tragedias que en su mayoría pasan desapercibidas, lejos de las cámaras de televisión y las preocupaciones pasajeras del Internet. Al final, el extractivismo puede reducirse en una fórmula sucinta: "acumular desposeyendo”. La obsesión extractiva ilumina, además, una maldición añeja: la incapacidad de las naciones latinoamericanas de escapar a su papel de productores de 
materias primas, siempre a merced de los vaivenes del mercado mundial. ${ }^{18} \mathrm{El}$ corolario es inevitable: las economías crecen, de cuando en vez, sobre el papel y, con todo, los beneficios no alcanzan a las grandes mayorías. Desde el 2015 la inequidad ha aumentada de forma considerable. En 2018, el número de pobres llegó al 30,1 por ciento de la población. En otras palabras: ciento ochenta y cinco millones de personas viven en la pobreza. Sesenta y seis millones, el 10,7 por ciento de los latinoamericanos, sobrevive en una situación de destitución extrema. Los avances sociales conseguidos en los primeros años del siglo se han ido erosionando con prisa y sin pausa.

Hasta aquí he enfatizado los comunes denominadores entre "Izquierda" y "derecha". Es necesario reconocer, también, sus diferendos. Me parece que la distinción de fondo radica en concepciones opuestas sobre el Estado y sus funciones. ${ }^{19}$ Intelectual y políticamente, tanto la derecha (de raigambre liberal cuando tiene que ver con la forma de gobierno) como la izquierda (forjada en el imaginario de la Revolución) provienen de tradiciones anti-estatales. El Estado, coinciden, es el gran responsable del estancamiento histórico, del camino trunco hacia la modernidad plena. La derecha le echa en cara su burocratismo, la ineficiencia administrativa, el proteccionismo comercial, la corrupción sistémica y sus trabas que desalientan la inversión privada. Por su parte, la izquierda ha visto en el Estado al garante de canonjías sociales que se extienden por generaciones. El instrumento que naturaliza la injustica y convalida las múltiples caras que toma la opresión. Más aún, desconfía de sus formas democráticas que disfrazan, asegura, su esencia represiva. Lo describe como un Dr. Jekyll que se comparta apropiadamente mientras las circunstancias le favorecen. Cuando le cambia la suerte, aparece el Mr. Hyde de los golpes de estado, las cámaras de tortura y los escuadrones de la muerte. En resumidas cuentas, la derecha suele apostar al Estado mínimo y la izquierda prescribe su refundación, abraza la lógica de la tabula rasa.

16 En teoría, el Estado liberal se pretende delgado y delicadamente musculoso. En otras palabras: eficiente y comprometido con la legalidad. En la práctica, el Estado en que sustenta el mercado en América latina, el realmente existente, se consagra a fines bien precisos. Sirve, por ejemplo, para externalizar los costos y evadir responsabilidades. Los beneficios son para los particulares y los costes los asume el erario público. El Estado se encarga de sostener precios de producción baratos y mantener mínimos niveles impositivos. Garantiza la flexibilidad laboral y asume los crecientes daños medioambientales. Defiende el libre comercio cuando conviene y protege de la competencia a los monopolios que le son consentidos. Es generoso a la hora de otorgar prestamos y servir como aval de la liquidez empresarial. Más importante aún, se trata de un Estado que se encarga de administrar altos niveles de desigualdad social y presidir sobre la violencia criminal cuyo crecimiento exponencial coincide en el tiempo con la liberalización de las economías latinoamericanas.

17 El Estado liberal tiene dos formas significativas para su auto-legitimación. La primera le viene de las transiciones hacia formas democráticas de gobierno que caracterizaron América latina en los años ochenta y noventa del siglo pasado. ${ }^{20} \mathrm{En}$ ese sentido, respeta las normas de la democracia liberal: elecciones limpias, libertad de prensa e independencia entre los distintos poderes estatales. En particular se interesa por un poder judicial robusto e intervencionista y un banco central defensor de una política monetaria ortodoxa. Estas características lo distingue del desorden institucional decimonónico y del autoritarismo represor del siglo XX. La otra fuente de su legitimidad ha sido una revolución en el consumo. El Estado liberal no ha formado 
ciudadanos sino consumidores. Latinoamérica ha encontrado en la vendimia que permite la mundialización un sucedáneo para las promesas incumplidas del desarrollo. Acceder a los bienes y servicios idolatrados internacionalmente permite, para decirlo en términos de Johannes Fabián, que el consumidor latinoamericano viva en el aquí $y$ ahora de la hipermodernidad ya no en allí y entonces del subdesarrollo. ${ }^{21} \mathrm{El}$ consumo realiza, aunque sea de manera ilusoria, el proyecto de Octavio Paz: ser, por fin, contemporáneos de todos los hombres. El centro comercial se ha vuelto el espacio público por antonomasia en la era del libre mercado y su Estado liberal. ${ }^{22}$

Para los gobiernos progresistas, la refundación del Estado no se ha dado gracias a la Revolución, que debería servir como revulsivo histórico, sino de la mano a un proceso más bien simbólico: la promulgación de nuevas constituciones. El progresismo construyó la figura heroica del "poder constituyente" ejerciendo su soberanía plena y dotándose de una forma original de organización política. ${ }^{23} \mathrm{En}$ la práctica ese poder constituyente, expresión del pueblo en movimiento, ha sido asimilada, como diría Hans Kelsen, al Grundnorm (Ley Fundamental) extraviando así su carácter revolucionario y radicalmente transformador. América latina es tierra fértil para la experimentación constitucional. ${ }^{24}$ Muchas y novedosas han sido las constituciones promulgadas a lo largo de su historia. Lo difícil es traducir los preceptos legales en práctica política. Valga rescatar una frase al gusto de los administradores del Impero español en las Américas: "la ley se acata pero no se cumple". Con frecuencia las constituciones de avanzada han terminado en compendios de buenas intenciones. Para los gobiernos progresista, basados en liderazgos robustos y decididamente ejecutivos, los ritmos deliberativos de sus constituciones han resultado frustrantes y con frecuencia prefieren gobernar por decreto, más allá de su propia ley. El ejemplo más claro es el de Nicolás Maduro en Venezuela.

19 Para el progresismo, el Estado es el único instrumento capaz de neutralizar los caprichos del mercado y la mundialización del laissez-faire. El Estado se concibe, además, como dispositivo útil para asegurar un reparto algo más equitativo de la riqueza. El problema con ésta concepción progresista del Estado es que ha dejado un sinfín de promesas por cumplir. Ha fallado en democratizar las estructuras del poder. Los esfuerzos por dinamizar los mecanismos de participación popular quedaron reducidos a la lógica plebiscitaria: con o contra nosotros. Se ha instrumentalizado al "pueblo" como un as bajo la manga que sirve en las ríspidas negociaciones con los dueños del capital. Más que formas de democracia participativa se ha experimentado con innovadores métodos corporativistas, clientelistas y de patronazgo. ${ }^{25}$ Ante la imposibilidad de instrumentar verdaderas revoluciones fiscales, los gobiernos progresistas han dependido de las políticas extractivas ${ }^{26}$ Mientras el mercado mundial compraba materias primas a precios justos hubo recursos para reducir la pobreza. Con la caída en el precio de los commodities los programas sociales no sólo perdieron fuelle sino se revelaron como incapaces de promover cambios duraderos. Recuerdo las palabras proféticas de Arturo Uslar Pietri, las políticas extractivas aseguran "abundancia momentánea y corruptora" y apuntan a la "catástrofe inminente e inevitable". ${ }^{27}$

20 A los gobiernos de la marea rosada le legitimidad les venía de reconocer, sin reservas, el déficit social que distingue a las sociedades latinoamericanas. Los gobiernos progresistas implementaron toda una batería de medidas de tinte social. Pienso en unos cuantos nombres que marcaron sus políticas públicas: Fome Zero y Bolsa Família en 
Brasil, las misiones venezolanas, el Bono Juana Azurduy y la Renta Dignidad en Bolivia, el Plan de Igualdad de Oportunidades ecuatoriano. Es indispensable analizar los éxitos y los límites de éstos programas desde el rigor de las ciencias sociales. Saber hasta dónde ayudaron a resolver problemas estructurales y hasta dónde promovieron un asistencialismo electoralista. Durante sus años de apogeo, las clases populares desarrollaron hábitos de consumo y gasto propios de las clases medias, cosa que se logró al través de créditos leoninos otorgados por el sector privado, como en el Brasil de Lula, y de generosas dadivas estatales. Resulta interesante pensar, en clave marxista, cómo el consumo creo una falsa conciencia que terminó por costar caro a los partidos de izquierda. Elegir candidatos es una de las formas que toma la distinción social. ¿Hasta qué punto votar por los políticos de derecha garantiza una pertenencia emocional, que no social, a las capas acomodadas de la sociedad? En Bolivia, Brasil y Ecuador las nuevas "clases medias" fueron paulatinamente mudando de signo político. Las administraciones progresistas sufrieron un enorme desgaste por sus frecuentes casos de corrupción. Los estados liberales lograron personalizar la corrupción y hacer ceremonias sacrificiales que permitía devolver la confianza en el sistema. Como decía líneas arriba, Perú ha juzgado a cuatro expresidentes, un ritual que permite a su clase política mantener un nivel mínimo de legitimidad. ${ }^{28}$ Guatemala se deshizo de Pérez Molina gracias a una significativa revuelta ciudadana. Los gobiernos progresistas socializaron, sin querer, la precepción de una ratería generalizada entre sus funcionarios públicos. Se cometieron, a mi parecer, dos errores fundamentales: 1) fueron incapaces de vivir en carne y hueso la austeridad e incorruptibilidad que se desprendía de su discurso, con la loable excepción de Pepe Mujica en el Uruguay; 2) pusieron poca atención a crear mecanismos administrativos y legales para prevenir el uso discrecional de los recursos públicos. No ayudó, por supuesto, la campaña de desprestigio constante puesta en marcha por los medios de comunicación antagónicos, la verdadera oposición a los gobiernos de izquierda, y que suele pasar por alto que para el tango de la corrupción se necesitan siempre dos bailarines: los políticos y los empresarios.

Es importante reparar en la administración de Andrés Manuel López Obrador en México. La primera en romper treinta y seis años de hegemonía neoliberal. Escribo sobre un político que pretende vaciar los moldes ideológicos que han regido a América latina durante las últimas dos décadas. López Obrador desplaza el debate de ideas del siglo XX al siglo XIX. ${ }^{29}$ Se declara liberal y tilda a sus adversarios de conservadores, de reaccionarios. Reclama para si mismo concepto de austeridad, como práctica de la moral cívica y como forma para adelgazar las instituciones publicas. En los primeros dos años de gestión, se ha reducido radical y aceleradamente las competencias y los presupuestos del Estado, tanto que hace poner en perspectiva los denostados recortes "neoliberales" del pasado reciente.

El suyo es un liberalismo con espíritu social. Una tradición que en Latinoamérica tiene un ilustre árbol genealógico y pasa entre otros nombres por Benito Juárez, José Martí, y Jorge Eliécer Gaitán. En México, el liberalismo social ha sido un experimento socorrido para promover la equidad sin pronunciar la palabra que más asusta a las buenas conciencias: socialismo, en cualquiera de sus variantes. Se trata de un liberalismo que se declara fiero enemigo de los privilegios heredados y es profundamente nacionalista. Cree, al contrario de los economistas neoclásicos, en el Estado como el mecanismo capaz de regular el comercio y planificar el "desarrollo". ${ }^{30}$ López Obrador es más 
personalista que autoritario. Hace de la voluntad y el ejemplo individuales los motores de la historia. Su enemigo categórico es la corrupción, la palabra en que según él se condensan todos los males de su país. ${ }^{31}$ Cree firmemente, como buen líder regional, en las bondades de la modernización y el progreso, de allí su entusiasmo por las grandes obras de infraestructura. Esta por verse si López Obrador se erige en modelo para otros países, queda como un caso más de la "excepcionalidad" de la vida política mexicana o termina por ser un personaje más en el drama que enfrenta a quienes apuestan por el Estado como gran rector de la vida económica y aquellos que defienden el libre mercado contra viento y marea.

\section{II}

La mutación más reciente de la familia de los coronavirus, el SARS-COV-2, aterrizó en Latinoamérica el 26 de febrero del 2020. El país más poderoso de la subcontinente confirmó su primer caso en São Paulo. Brasil se encontró, una vez más, a la vanguardia de las fuerzas de la mundialización en su zona de influencia. A los pocos meses, el ensayista argentino Juan José Sebreli se declaró asombrado ante un fenómeno de carácter tan decididamente universal. ${ }^{32}$ Los efectos de la pandemia se sentían a la misma vez en Paris que en Buenos Aires; en Roma que en Rio de Janeiro; en Berlín que en Lima; en Nueva York que en la Ciudad de México; en Beijing que en Santiago de Chile. La tragedia igualaba al mundo e imponía un mismo espacio histórico-temporal. La mundialización había vuelto a desembarcar en las Américas con la más poderosa y persuasiva de sus armas: un virus.

Los primeros casos de la infección que alanzaron notoriedad en América latina fueron los de hombres de negocios que se contagiaron en lugares remotos: Cortina d'Ampezzo, el Barrio de Salamanca en Madrid, la Concesión Francesa en Shanghái o algún edificio corporativo en la zona de Gangnam en Seúl. Miguel Barbosa, el gobernador del estado mexicano de Puebla, sentenció que el coronavirus era una enfermedad de ricos, una venganza de la naturaleza para castigar sus ambiciones desmedidas. Profetizó, además, que los pobres serían inmunes ante una enfermedad tan justiciera, un virus que escogía sus víctimas de acuerdo a criterios socioeconómicos. Barbosa tuvo que comerse sus palabras. Los epicentros del virus han sido las áreas socialmente más vulnerables. Las favelas del Brasil, las villas de Buenos Aires, las alcaldías populares en la Ciudad de México. La pandemia se ha ensañado también con las regiones más vulnerables de la Amazonía. El coronavirus entró por sus ciudades (Manaos, Iquitos, Coca, Leticia, Belém) y de allí penetró en las comunidades indígenas que tratan de mantener una prudente distancia de las sociedades con quien se ven obligadas a coexistir. Ni que decir de las cárceles sobrepobladas de la región o los campos de refugiados en México, donde miles de centroamericanos esperan contra toda esperanza un salvoconducto de asilo de la administración Trump.

Las evidencias de la magnitud del problema llegaron, primero, desde Guayaquil. Las instantáneas tomadas con teléfonos móviles mostraban cuerpos abandonados en las calles de la ciudad portuaria del Ecuador. Esos cadáveres desatendidos anunciaban el colapso del sistema hospitalario y la inhabilidad del Estado para lidiar con la más esencial de sus funciones: hacer de la muerte un asunto privado, algo que sucede puertas adentro. El segundo ejemplo vino desde la Ciudad de México. El gobierno daba cifras tan halagüeñas que se empezó a sospechar de su veracidad. Pronto se descubrió 
que los hornos crematorios trabajaban sin descanso. En las morgues se apiñaban los cuerpos en el piso. No había refrigeradores suficientes para guardar a los occisos. Conforme los gobiernos se decidieron por la implementar una cuarentena general y obligatoria reapareció un viejo fantasma del subdesarrollo: el hambre. En Guatemala y El Salvador se ondearon banderas blancas para identificar a las familias a las que se les había acabado tanto la comida como el dinero. La novela de Leonardo Oyola, Kryptonita (2011) ya no sólo representa la resurrección de la literatura fantástica latinoamericana injertando el imaginario de DC Comics. ${ }^{33} \mathrm{El}$ hospital destartalado y los médicos extenuados que describe Oyola se han convertido, en tiempos del coronavirus, en una crónica de hechos. Un relato naturalista de males hoy más evidentes que nunca: servicios público moribundos, presupuestos sociales raquíticos y la violencia como el medio de intercambio por excelencia.

En el Perú ocurrió lo insólito. Por décadas un flujo migratorio imparable condujo a millones de personas de las provincias hasta las periferias de Lima, un fenómeno excepcionalmente documentado por Aníbal Quijano. ${ }^{34} \mathrm{El}$ Coronavirus logró revertir en unos cuantos días una de las características fundamentales de la modernidad latinoamericana, el crecimiento descontrolado de la ciudad. Ríos humanos decidieron abandonar la capital en busca de sus lugares de origen. Lima la horrible, para recordar a Sebastián Salazar Bondy, ya no daba para comer. El milagro de la repoblación de los pueblos del Perú fue atajado por las fuerzas de seguridad que temían que con los retornados se expandiera el virus a lo largo y ancho de la geografía nacional. Algo similar ha sucedido en la frontera entre Venezuela y Colombia. Miles de venezolanos han regresado a su terruño. Los otrora exiliados políticos se han convertido en repatriados por razones sanitarias.

Jair Bolsonaro ha sido coherente con la retórica que lo llevó a la presidencia. Ha declarado a la pandemia como una conjura, un invento para minar la resurrección nacional que él mismo encabeza. Desestimó el miedo al coronavirus posteando una frase del fascismo italiano en su muro de Facebook: "Es mejor vivir un día como un león, que cien años como un cordero." ${ }^{35}$ Bolsonaro terminó por contagiarse de la enfermedad después de un sinnúmero de apariciones en público en que ponían en duda la política de Estado que recomendaba el aislamiento social. Bolsonaro salió a la calle a arengar multitudes tantas veces como le fue posible. En el extranjero se le calificó como un político propio de un exuberante país tropical. En Brasil, la oposición cuestiona su estabilidad mental. Más bien, me parece, Bolsonaro está inventando las claves de una nueva derecha fascistoide. Para la cual es menos importante conquistar el poder que deslegitimarlo desde adentro. Bolsonaro se ha dedicado a ser el líder de la oposición. Se opone a las instituciones del Estado en su conjunto. Con la única salvedad de las fuerzas armadas a las que ha dado un lugar de privilegio en su gabinete y en la (des)administración de la República. Bolsonaro ha descubierto que la presidencia es una tribuna excepcional, una enorme caja de resonancia para promover ideas tan enloquecidas como aparentemente hechiceras. Da la impresión que oligarquía brasileña mantendrá su apoyo tácito al presidente mientras conserve en su cargo a Paulo Guedes, Ministro de Economía y fundador del Instituto Millenium. El hombre que promueve en el Brasil una versión libertaria de la economía y trabaja por un gobierno reducido a su mínima expresión. En Brasil se esta gestando un matrimonio que puede definir las décadas por venir en América latina, la unión entre el autoritarismo interesado en las guerras culturales y una segunda oleada del neoliberalismo. 

obrador, considerado a la izquierda del espectro electoral, ha sido poco entusiasta de imponer una cuarentena larga y severa. Sus opositores lo acusan de irresponsable, de ofrecer vidas humanas en la piedra sacrificial de la economía. En la Argentina, Alberto Fernández se ha decantado por un estricto confinamiento social. Su oposición, que ocupan la misma franja socioeconómica a los adversarios de López Obrador en México, lo acusan de autoritarismo, de hundir irremediablemente las finanzas de la nación. Algunos llegan al extremo de asegurar que la cuarentena es el ensayo general para el comunismo que se prepara tras bambalinas. ${ }^{36} \mathrm{Al}$ supuesto despotismo de Fernández, contrastan el ejemplo del Presidente de Uruguay. Lacalle Pau optó por permitir la "libertad responsable" de los ciudadanos. Busca, asimismo, embelesar a los inversionistas sudamericanos haciendo de su país una especie de paraíso fiscal, un cruce entre Suiza y las Islas Caimán.

Se estima que la actividad económica latinoamericana se contraerá en 9,2 por ciento en 2020. Al terminar el año, el PIB per cápita en América Latina será igual al de 2010. En cinco meses de pandemia se perderá la riqueza acumulada durante los últimos diez años. ${ }^{37}$ La economía sufrirá el parón derivado de los días de confinamiento en que la actividad productiva se redujo considerablemente. Sufrirá, además, por su exacerbada dependencia a los flujos del mercado mundial que mantienen sus economías a flote. Baste mencionar cuatro variantes de importancia: la baja en los precios de sus materias primas; la escasez del turismo internacional; la exigua inversión extranjera directa; el freno en el envío de remesas por parte de los trabajadores migrantes. Los gobiernos han ensayado algunas medidas para paliar los estragos de la crisis social y económica derivada del COVID-19. Argentina, Ecuador y Paraguay han provisto programas para proveer dinero en efectivo y comida a quien lo necesite. Chile, Colombia y Perú han seguido el modelo europeo cubriendo salarios caídos y otorgando préstamos preferenciales a pequeñas y medianas empresas. El Senado brasileño pasó la Ley 13.982, el "coronavaucher", que ofrece a los trabajadores informales algo parecido a una renta básica universal. El apoyo otorga noventa euros mensuales por tres meses. Pasa que éstos son gestos significativos $\mathrm{y}$, sin embargo, resultan insuficientes. Los países latinoamericanos tienen poco margen para desplegar un repertorio amplio de políticas monetarias que ayuden a aliviar los efectos más perniciosos de la depresión. El virus llegó en un momento de considerable debilidad financiera.

31 Este número especial parte de una premisa que creo ha quedado clara páginas arriba: Latinoamérica esta en crisis. Nos interesa en rastrear cómo investigadores comprometidos con América Latina piensan sobre la crisis y descubren razones para el optimismo. Cuatro líneas animan los artículo que aquí recopilamos: 1) La crítica al Estado neoliberal y el rastreo de incipientes subjetividades políticas. Esas que han hecho su aparición en las recientes protestas populares en Nicaragua, Chile y Colombia. Más aún. Tres movimientos sociales están cambiando la dinámica ideológica y las formas de hacer política en la región: a) el feminismo de nuevo cuño, en parte inspirado por una de nuestras colaboradas, Rita Segato; b) el resurgir de los pueblos originarios de Abya Yala; c) el de los jóvenes que en algo recuerdan a los de Primavera Árabe. 2) La critica al desarrollo y a la modernidad como piedras angulares de las naciones latinoamericanas. En ese sentido ponemos especial atención a una nueva concepción de la economía cuyo énfasis esta en el decrecimiento, la circularidad y el buen vivir. 3) La crítica al papel colonizador de los Estados nacionales a doscientos años de vida 
independiente. Estados que no sólo ha impuesto un idioma y una cultura dominante sino que ha sometido a los territorios a las presiones del extractivismo. 4) Una historia cultural que rastree las ideas que escapan a los patrones ideológicos dominantes. Patrones que no sólo empobrecen el debate público sino que atrofian la capacidad de encontrar salidas al laberinto latinoamericano.

\section{NOTES}

1. "Our work in Nicaragua," Transparency International, https://www.transparency.org/en/ countries/nicaragua.

2. La respuesta latinoamericana más visible a la crisis del 2008 en Estados Unidos y Europa fue la recisión brasileña de 2015-2016 y la crisis de la deuda argentina que minó al gobierno de Mauricio Macri y cuyos legados limitan, también, a la administración de Alberto Fernández.

3. Fernando Escalante Gonzalbo, Se supone que es ciencia: reflexiones sobre la nueva economía, Ciudad de México, El Colegio de México, 2017.

4. Sarah Babb, "Neoliberalism and the Rise of New Technocrats" in Managing Mexico: Economists from Nationalism to Neoliberalism, Princeton, Princeton University Press, 2018; Patricio Silva, In the Name of Reason: Technocrats and Politics in Chile, University Park, The Pennsylvania State University Press, 2009.

5. William Wheeler, State of War: MS-13 and El Salvador's World of Violence, New York, Columbia Global Reports, 2020.

6. Referirse a la investigación sobre la desaparición forzada de 43 estudiantes de Ayotzinapa hecha por la plataforma de investigación Forensic Architecture de Goldsmiths, Universidad de Londres: https://forensic-architecture.org/investigation/the-enforced-disappearance-of-theayotzinapa-students.

7. "Global Study on Homicide 2019," United Nations, https://www.unodc.org/unodc/en/data-andanalysis/global-study-on-homicide.html.

8. "Feminicidio," Observatorio de Igualdad de Género de América Latina y el Caribe, https:// oig.cepal.org/es/indicadores/feminicidio

9. Rita Segato, Contra-Pedagogías de la Crueldad, Buenos Aires, Prometeo Libros, 2018, p. 13.

10. Charles H. Blake, Stephen D. Morris (eds), Corruption \& Democracy in Latin America, Pittsburgh, University of Pittsburgh Press, 2009.

11. Jorge González, Odebrecht: la historia completa, Bogotá, Editorial Aguilar, 2018.

12. Sobre el populismo de izquierda en América Latina: Chantal Mouffe e Íñigo Errejón, "L'Amérique latine et les expériences national-populaires" in Construire un people. Pour une radicalisation de la démocratie, Paris, Les Éditions du Cerf, 2017.

13. “'La Biblia vuelve a entrar a Palacio': Jeanine Añez, presidenta interina de Bolivia," El País, 13 November 2019, https://www.elpais.com.co/mundo/la-biblia-vuelve-a-entrar-a-palacio-jeanineanez-presidenta-interina-de-bolivia.html.

14. Baste recordar que en las últimas décadas, dieciocho presidentes latinoamericanos no han terminado su mandato. Referirse a un estudio primerizo sobre el tema: Arturo Valenzuela, "Presidencias latinoamericanas interrumpidas", América Latina Hoy, 49, 2008, pp. 15-30. 
15. Abraham Weintraub, "Salmos $94: 23$. 'O Senhor fará recair sobre eles a sua própria iniqüidade, e os destruirá na sua própria malícia; o Senhor nosso Deus os destruirá'," Twitter, 10 March 2020, https://twitter.com/abrahamweint/status/1237364628302319616?lang=en.

16. Daniel Mato, "Pandemia, racismo y derechos humanos," Archivos del Presente, 15 de Julio 2020 https://archivosdelpresente.com/articulos/pandemia-racismo-y-derechos-humanos/.

17. Macarena Gómez-Barris, The Extractive Zone: Social Ecologies and Decolonial Perspectives, Durham NC, Duke University Press, 2017. Gómez Baris demuestra que el extractivismo no sólo causa devastación sino que también genera importantes resistencias con el empuje necesario para formar nuevas subjetividades políticas.

18. Dawid Danilo Bartelt, Naturaleza y conflicto: la explotación de recursos en América Latina, Ciudad de México, Akal, 2019.

19. Menno Vellinga (ed.), The Changing Role of the State in Latin America, New York, Routledge, 2018.

20. Guillermo O'Donnell, Philippe C. Schmitter, Laurence Whitehead (eds), Transitions from Authoritarian Rule. Vol 2: Latin America, Baltimore, The Johns Hopkins University Press, 1993.

21. Johannes Fabian, Time and the Other: How Anthropology Makes Its Object, New York, Columbia University Press, 2014.

22. Arlene Dávila, El Mall: The Spatial and Class Politics of Shopping Malls in Latin America, Oakland, University of California Press, 2016.

23. Antonio Barreto Rozo, Nicolás Figueroa García-Herreros, Jorge González Jácome (coordinadores), Poder constituyente a debate: perspectivas desde América Latina, Bogotá, Universidad de los Andes, 2020.

24. Roberto Gargarella, Latin American Constitutionalism,1810-2010: The Engine Room of the Constitution, New York, Oxford University Press, 2013.

25. Tina Hilgers (ed.), Clientelism in Everyday Latin American Politics, New York, Palgrave Macmillan, 2012. Me interesa citar, asimismo, el documental de Martín Andrés Markovits sobre Alberto "Chino" Carías, líder del Colectivo Tupamaros en la Parroquia 23 de Enero en Caracas. La película de Markovits es un testimonio imprescindible para entender algunas de las formas que ha tomado el clientelismo en la Venezuela bolivariana. Martín Andrés Markovits (director), Tupamaro: Urban Guerrilla, Bucarest, The Underground, 2019.

26. Eduardo Gudynas, "El nuevo extractivismo progresista", Nueva Crónica, 30 de enero al 11 de febrero del 2010.

27. Arturo Uslar Pietri, "Sembrar el Petróleo," Diario Ahora, 14 de Julio de 1936.

28. En éste punto, me inspiro en el trabajo de Jeffrey C. Alexander. Pienso en particular en su ensayo "Watergate as Democratic Ritual" recopilado en el libro The Meanings of Social Life: A Cultural Sociology, Oxford, Oxford University Press, 2003.

29. Andrés Manuel López Obrador, Neoporfirismo: hoy como ayer, Ciudad de México, Editorial Grijalbo, 2014.

30. Andrés Manuel López Obrador, "Rescatar el Estado" en 2018: La salida, Ciudad de México, Editorial Planeta, 2017.

31. Andrés Manuel López Obrador, Hacia una economía moral, Ciudad de México, Editorial Planeta, 2019.

32. Juan José Sebreli entrevistado por Pablo Sirvén, "Hablemos de Otra Cosa," La Nación TV, 8 de mayo del 2020.

33. Leonardo Oyola, Kryptonita, Buenos Aires, Random House, 2011.

34. Aníbal Quijano, Dependencia, Urbanización y cambio social en Latinoamérica, Lima, Mosca Azul Editores, 1977; Aníbal Quijano, Dominación y cultura: lo cholo y el conflicto cultural en el Perú, Lima, Mosca Azul Editores, 1980.

35. Guilherme Amado, "Bolsonaro Posta Frase De Mussolini”, Epoca, 5 de junio del 2020: https:// epoca.globo.com/guilherme-amado/bolsonaro-posta-frase-de-mussolini-24456489. 
36. "Marcha contra el comunismo: una convocatoria desopilante con respuestas aun más desopilantes," Pagina 12, 6 de Mayo del 2020, https://www.pagina12.com.ar/264212-marchacontra-el-comunismo-una-convocatoria-desopilante-con-.

37. Para obtener datos económicos actualizados consultar la página del observatorio de la CEPAL que rastrea los efectos del COVID-19 en Latinoamérica: https://www.cepal.org/en/topics/ covid-19. 